Cita bibliográfica: Bertan, S. y Altintas, V. (2017). The Attitudes of hotel managers towards reviews. Investigaciones Turísticas (14), pp. 154-163. https://dx.doi.org/10.14461/INTURI2017.14.08

\title{
Attitudes of hotel managers towards reviews
}

\section{Actitud de los directores de hotel ante las opiniones de los clientes}

Serkan Bertan.Pamukkale University, Faculty of Tourism, Turkey. serkanbertan@yahoo.com Volkan Altintas. Izmir Katip Celebi University, Faculty of Tourism, Turkey. volkan altintas@hotmail.com

\section{ABSTRACT}

The purpose of this study is to evaluate the attitudes of hotel managers towards online reviews. The sample of this quantitative study consists of all the 4 and 5 star hotels in Turkey which have tourism operation licences. The questionnaire form designed for this study is sent to hotel managers in Turkey via electronic mail. The questionnaire form is sent to the entire 4 and 5 star hotels with tourism establishment licenses in three different times in 2016 because of remind. The number of collected questionnaire forms are 155, but 120 of them is regarded as valid and included in the analyses. The data is analysed by SPSS 16. After the analyses, it is found that there is a relationship between hotel and users and responding. The results of this study provide valuable information that can be useful for hotel managers in terms of customer retention.

Keywords: Hotel Manager, reviews, online reviews.

\section{RESUMEN}

El propósito de este estudio es evaluar las actitudes de los directores de hotel ante las opiniones online de los clientes. La muestra de este estudio cuantitativo consiste en todos los hoteles de 4 y 5 estrellas en Turquía que tienen licencias de operación turística. El cuestionario diseñado para este estudio se envía por correo electrónico a los directores de hotel en tres momentos diferentes de 2016. El número de formularios del cuestionario recopilados es 155, de los que 120 se consideran válidos e integran el análisis. Los datos son analizados por SPSS 16. Los resultados de este estudio proporcionan información valiosa que puede ser útil para los gerentes de hotel en términos de retención de clientes.

Palabras clave: Director de hotel, críticas, comentarios en línea.

\section{INTRODUCTION}

Online reviews written for narrating experiences (Ong, 2012), which eliminate uncertainties before purchase decision (Trevino and Castano, 2013) are important sources for consumers (Trevino and Castano, 2013; Racherla, Connolly, Christodoulidou, 2013; Gu and Ye, 2014, Browning et al., 2013; Korfiatis and Poulos, 2013; Sparks et al., 2013). In recent years, the importance of online reviews to behaviours and attitudes of consumers has been emphasized in researches more often (Park and Allen, 2013; Browning et al., 2013) and the 
effects of online reviews on purchase intentions have become a topic of interest among academics (Treviño and Castaño, 2013). Online reviews read by consumers while making travel plans play a substantial role in hotel choice (Stringam et al., 2010). The reviews in addition to product information are found to be more credible and to increase purchase intentions of consumers (Jimenez and Mendoza, 2013). Personal information within reviews has an impact on whether reviews help other consumers (Lee, Law and Murghy, 2011), consumers' booking intentions and their decisiveness during hotel review process (Xie, Miao, Kuo and Lee, 2011). The present study is expected to reveal the information to which managers give importance in reviews and the relationship between the information they take into consideration and their responses.

\section{LITERATURE REVIEW}

To increase purchase intentions and trust of consumers, different responding strategies are being used in parallel with the rating of positive and negative reviews (Purnawirawan, Pelsmacker and Dens, 2012; Park and Allen, 2013). Hotel managers should determine why they respond to reviews and what affects their decision while responding (Park and Allen, 2013). In literature, there are only a few studies on responding to online consumer reviews (Park and Allen, 2013). When the effect of responding to negative reviews about purchase intentions is examined, it is found that managers choose to deny, agree and change while responding and they think that if they change the situation by apologizing or promise to change the problematic situation, purchase intentions of consumers increase and this creates a positive impression for hotel (Trevino and Castano, 2013). Specifically, management responses, which are important to service businesses, refer to responding to the comments and forming an interaction according to products, services or experiences (Gu and Ye, 2014). In general, negative reviews are responded (Trevino and Castano, 2013; Xie, Zhang and Zhang, 2014), however the effect of responding to other potential consumers is not known (Trevino and Castano, 2013). While responding to reviews, managers usually apologize, thank, explain, wish that customers come again, follow, fix and cover expenses (Levy, Duan and Boo, 2013; Purnawirawan, Pelsmacker and Dens, 2012; Trevino and Castano, 2013).

Most of the hotel manager's responsiveness rate is low. Mostly four or five stars hotel manager's response the negative comments often and guest service managers also respond the comments (Lee and Blum, 2015).

Online user reviews are responded in order to solve the problems in a cautious and effective way and get in contact with guests efficiently (Park and Allen, 2013). Responding to reviews has some substantial effects such as increase in online reservation, increase in customer satisfaction in terms of hotel experiences and increase in the hotel's popularity in market (Xie, Zhang and Zhang, 2014). Also, responding to negative reviews of displeased consumers who grade a hotel negatively increases their satisfaction level and makes them repurchase (Xie, Zhang and Zhang, 2014). When consumer reviews are responded, almost $80 \%$ of tourists believe that their opinions are taken into consideration and $84 \%$ of them think that management responses increase hotel's positive impression (Breiure, 2013). There are 144 review sites right now, 26 of which offer managers the opportunity to respond online user reviews (Olery, 2012). 


\section{THE METHOD OF STUDY}

The sample of this study consisted of all the 4- and 5- star hotels in Turkey with tourism operation licences which were given by the Ministry of Culture and Tourism for legal operation of hotels. For the purpose of evaluating the attitudes towards reviews, a questionnaire form was designed. This form included questions about online reviews and the demographic characteristics of participants. In the questionnaire, it is declared that all responses will be secret. It consists of preference for online comments and demographic questions. The questionnaire was designed in accordance with the aim of this study, and it was sent to the managers of 20 accommodation facilities in different cities for preliminary study via e-mails. For field study, questionnaires were first sent to 20 hotels for validity and reliability analyses applied to the scale. After validity and reliability were confirmed, questionnaire forms were sent to the managers of all the 4-5 star hotels in Turkey which had tourism operation licenses. Within the scope of this study, the survey was conducted with the facilities with tourism operation licenses via telephones and electronic mails. One month later, questionnaires were sent again to the hotels of which managers had not completed the questionnaires as a reminder. Then two months later questionnaires were sent for one last time. The accommodation facilities are selected from all the facilities registered to the Ministry of Culture and Tourism and that means they have tourism operation licenses which allow facilities to operate in a legal way.

The questionnaire form consisted of four parts, the first part of which involved statements about online reviews; in the second part, there were statements about managers' attitudes towards online reviews. In the third part, there were statements about the effects of online reviews and in the fourth part; there were questions about demographic information of participants. The statements were related to how often managers read online reviews; which kinds of reviews they cared about most (negative or positive reviews); whether they got in touch with online users; what kind of reviews they paid attention to and which websites they cared about most. In addition to these, there were statements related to the effects of online reviews on businesses.

In order to remind to the respondents to complete the survey, the questionnaire form was sent to all the 4- and 5- star facilities with tourism operation licenses in three different times. After this, the number of managers, who filled the questionnaire form, was 155; however as some parts of 35 questionnaires were missing, 120 questionnaires were included in the analyses. The data gathered from questionnaires was analysed with SPSS 16.

The questionnaires were checked if they were filled completely or not, if the answers continued in a regular way or not. Also, extreme values and missing values were checked too in order to find out if missing data was random or not and if data set distributed normally or not.

\section{THE FINDINGS OF STUDY}

The demographic characteristics of the participants can be seen from Table 1. According to this data, almost $30 \%$ of the managers were women, $70 \%$ of them were men. As for education, $12.5 \%$ of managers were high-school graduate, $75 \%$ were college graduate and $15 \%$ had a Master's Degree. Considering the ages of participants, almost $17 \%$ the participants were under $30 ; 20 \%$ were between $31-35 ; 22.5 \%$ were between $36-40 ; 18.3 \%$ were between $41-45 ; 22.5 \%$ were above 46. 
Table 1: Demographic Characteristics of the Sample

\begin{tabular}{|l|c|c|l|c|c|}
\hline & $\mathrm{F}$ & $\%$ & & $\mathrm{~F}$ & $\%$ \\
\hline Gender & & & Operation Period & & \\
\hline Female & 35 & 29.2 & Open all year round & 85 & 70.8 \\
\hline Male & 85 & 70.8 & Seasonal & 35 & 29.2 \\
\hline Education & & & Operating For & & \\
\hline High school & 15 & 12.5 & 5 years and less & 26 & 21.7 \\
\hline Undergraduate & 90 & 75 & $6-10$ & 24 & 20 \\
\hline Graduate & 15 & 12.5 & $11-15$ & 26 & 21.7 \\
\hline Age & & & $16-20$ & 13 & 10.8 \\
\hline 30 and below & 20 & 16.7 & 21 and more & 31 & 25.8 \\
\hline $31-35$ & 24 & 20 & Business Status & & \\
\hline $36-40$ & 27 & 22.5 & Independent business & 64 & 60.5 \\
\hline $41-45$ & 22 & 18.3 & Chain business & 56 & 46.7 \\
\hline 46 and above & 27 & 22.5 & & & \\
\hline
\end{tabular}

When operation periods of facilities were considered, $70.8 \%$ of them were open all year round and $29.2 \%$ were open seasonally. Also, it was found that $60.5 \%$ of facilities were independent businesses; $46.7 \%$ of them were chain businesses. Almost $20 \%$ of hotels had been in operation for less than 5 years, $20 \%$ of them had been operating for $6-10$ years; $21.7 \%$ for $11-15$ years; $10.8 \%$ for $16-20$ years and $25.8 \%$ had been in operation for more than 21 years.

Almost $60 \%$ of managers read the reviews consistently; $27.5 \%$ read very often; $10.8 \%$ read occasionally; $8 \%$ read sometimes. Most of the managers (93\%) gave priority to negative reviews; almost $6 \%$ of them to positive reviews. Almost $55 \%$ of managers got in contact with website administration for negative reviews; almost $45 \%$ of them did not. Almost $73 \%$ of managers gave importance to reviews about service, $15 \%$ of them about cleanliness, $5 \%$ of them gave importance to reviews about facility atmosphere; $4.2 \%$ about food; $1.7 \%$ of them about sleep quality and the rest gave importance to the reviews about rooms. For examining online reviews, $20.6 \%$ of managers followed Tripadvisor, $18.3 \%$ followed booking.com and $11.8 \%$ followed holidaycheck. 
Table 2: The Effects of Online Reviews

\begin{tabular}{|c|c|c|}
\hline \multirow[b]{2}{*}{ Statement } & \multicolumn{2}{|c|}{$\begin{array}{l}\text { The percentage of } \\
\text { responses }\end{array}$} \\
\hline & 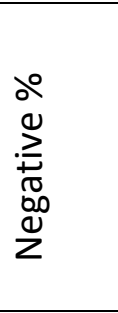 & 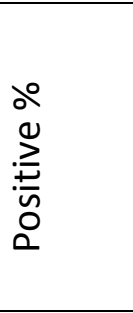 \\
\hline affect sales. & 4.2 & 92.3 \\
\hline increase our marketing efficiency. & 4.2 & 90 \\
\hline enable our services to be rendered in a better way. & 7.5 & 84.2 \\
\hline improve the relationship with our guests. & 9.2 & 81.7 \\
\hline increase the recognition of our products. & 5.8 & 86.7 \\
\hline give competitive advantage. & 5 & 85 \\
\hline strengthen guest relations. & 8.4 & 80.2 \\
\hline affect purchasing decisions of consumers. & 5.9 & 90 \\
\hline are important for monitoring the tendencies of guests. & 6.7 & 85 \\
\hline are a substantial tool for specifying guest complaints. & 5 & 89.2 \\
\hline $\begin{array}{l}\text { are an efficient tool for understanding how guests perceive our } \\
\text { products. }\end{array}$ & 5.9 & 88.3 \\
\hline
\end{tabular}

Table 2 represents the effects of online reviews with percentages of responses. When the effects of online reviews were asked, a great majority of hotel managers (between $81 \%$ and 92\%) admitted that sales were affected; marketing efficiency increased; services were rendered in a better way; relations with guests improved; recognition of products increased; competitive advantage was provided; guest relations strengthened; purchasing decisions of consumers were affected, and online reviews were an important tool for monitoring consumer tendencies, determining guest complaints and determining how guests perceived the products.

By using a statistical program, the reliability test was applied to the data. Factor analysis was applied in order to determine a certain reliability, to make data reduction and to determine internal validity. In this study, as the sample size was above 100 , factor analysis was carried out ( $p=0.001$ level) and Kaiser-Meyer-Olkin sample value was 0.890 which were within the acceptable limits and could be interpreted as good. Varimax rotation was applied in the factor analysis. After analysing scree plot graphic, data of which eigenvalue was above 1 (Eigenvalue $>1$ ) was included in the analyses. Besides this, in order to decide the validity of factor analysis, the option of anti-image, coefficients and KMO and Barlett's Test of Sphericity were applied. As sig. value in Barlett's Test of Sphericity was 0.001 , it was significant. As a result, these tests showed that factor analysis could be applied to the data. When explaining 0.40 or above variance was considered, it was found out that only three factors could correspond it. Since common variance values of each one of the variables were above 0.64 , they were not applied to any kind of process. In this study, for presenting intensive relationship within the rotated components matrix, factor loads of 0.40 and below were not taken into consideration and it was determined that factor loads occurred between 0.544 and 
0.866. As a result of this, it was observed that there was a close relationship between variables and components. Fifteen variables were gathered under three factors; they defined total variance at the rate of $64.778 \%$. Three factors determined after factor analysis and the variables of these factors can be seen from Table 3 below.

Table 3: Summary Results of Factor Analysis

\begin{tabular}{|c|c|c|c|c|}
\hline Factors & 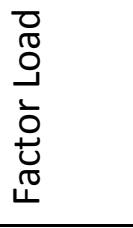 & 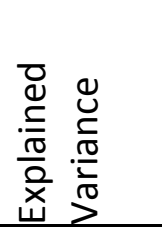 & $\frac{\frac{\pi}{2}}{\frac{2}{2}}$ & $\sum_{\substack{\mathbb{N} \\
ٍ}}^{\frac{\Gamma}{d}}$ \\
\hline Hotel & & 30.510 & 0.924 & 4.380 \\
\hline The favour rating of the hotel in region & 0.866 & & & \\
\hline $\begin{array}{l}\text { The rank of hotel in region in terms of } \\
\text { consumer favour }\end{array}$ & 0.852 & & & \\
\hline $\begin{array}{l}\text { Summary of grades given to the hotel in } \\
\text { general }\end{array}$ & 0.770 & & & \\
\hline The rank of hotel in region & 0.731 & & & \\
\hline Negative reviews on hotel & 0.643 & & & \\
\hline Personal grading of hotel & 0.594 & & & \\
\hline Positive reviews on hotel & 0.544 & & & \\
\hline Users & & 18.578 & 0.810 & 3.603 \\
\hline The pictures that users add & 0.577 & & & \\
\hline The titles of reviews & 0.596 & & & \\
\hline The number of previous reviews & 0.719 & & & \\
\hline $\begin{array}{l}\text { The number of hotels on which users write } \\
\text { reviews }\end{array}$ & 0.800 & & & \\
\hline The nationalities of reviewers & 0.661 & & & \\
\hline Reviews & & 15.690 & 0.762 & 4.214 \\
\hline The return intention of reviewers & 0.711 & & & \\
\hline The rate of recommendation & 0.634 & & & \\
\hline The number of useful reviews & 0.621 & & & \\
\hline
\end{tabular}

The clarification rate of total variance $=64.778 \%$ and $p \leq 0.001$; Kaiser-Meyer-Olkin sample value $=0.890$

Explained variance described by the first factor was $30.510 \%$ and it was represented by seven variables. The variables under this factor were related to the favour rate of hotel in region, the rank of hotel in region in terms of favour, summary of grades given the hotel in general, the rank of hotel in region, negative reviews on hotel, personal grading of hotel and positive reviews on hotel. As a result of factor analysis, statements related to the rating of hotel within the region, its rank, the summary of grades given to hotel, negative reviews about hotel, individual grading for the hotel and reviews about hotels in general were gathered under a factor. According to the statements, the first factor was named as "hotel".

Explained variance described by the second factor was $18.578 \%$ and it was represented by five variables. The variables under this factor were variables related to the pictures that users added, the titles of reviews, the number of previous reviews, the number of hotels on 
which users wrote and the nationalities of reviewers. The statements related to the photos online users added, the titles of online reviews, the number of reviews an online user had written, the number of hotels an online user had written reviews about and the nationalities of online users were gathered under another factor and this factor was named as "users".

Explained variance described by the third factor was $15.690 \%$ and it was represented by three variables. The variables under this factor were variables related to the return intention of reviewers, the rate of recommendation and the number of useful reviews. The statements related to return intention of online users; the rate of recommendations and the rate of usefulness of online reviews were gathered under another factor which was named as "reviews". The mean of the first factor was 4.380; the mean of the second factor was 3.603 and the mean of the third factor was 4.214.

In this study, the method of multiple regression analysis was used in order to test if there was a relationship between variables. From Table 4 below, results of regression analysis, which affected responding, can be seen.

Table 4: Results of Regression Analysis

\begin{tabular}{|l|c|c|c|c|}
\hline Variables & Beta & $\mathrm{t}$ & Sig t & VIF \\
\hline (Stables) & 2,228 & 1.122 & .264 & - \\
\hline Hotel & 0.288 & 2.536 & .012 & 2.115 \\
\hline User & 0.310 & 2.965 & .004 & 1.793 \\
\hline Review & 0.008 & 0.070 & .944 & 2.155 \\
\hline Multiple Regression =0.542 & \multicolumn{2}{|c|}{$\mathrm{p}=0.001$} \\
\hline Adjusted R Square =0.275 Square $=0.293$ & $\mathrm{~F}=16.048$ \\
\hline VIF=Variance Increase Factor & \multicolumn{5}{|l}{ Durbin-Watson=2.088 } & \multicolumn{2}{l|}{} \\
\hline
\end{tabular}

As it can be seen from Table 4, F value was 16.048 and significant was at the level of $p=0.001$; also the model was significant as a whole at every level. In the statistical values of parameters, it can be seen that variables hotel and users (Sig. $=<0.05$ ), which affected responding, were significant. As Durbin-Watson test value of variables (2.088) was between 1.5 and 2.5, there was not any autocorrelation. The result of Durbin-Watson test proved that this finding was not random and reflected the true situation.

Regression analysis was used to determine the importance level of independent variables (hotel, user, and review) on dependent variable (responding) and as a result independent variables explained, 275 percent of dependent variable. For the aim of determining significance levels of independent variables in relation to dependent variable in regression analysis, Sig. values and $\beta$ (Beta) levels were examined. It was observed that variables affected managers' responding to a considerable extent. The independent variable, which confirmed dependent variable in the best way, was "users" ( $p=0.004)$. This factor was followed by "hotel" factor ( $p=0.012$ ). According to these findings, there was a positive relationship between responding and the importance given to online reviews by managers firstly under the factors of "user" and "hotel". 


\section{CONCLUSION AND SUGGESTIONS}

In this study, a number of variables were discussed from different point of view, including the favour rating of the hotel in region, the rank of hotel in region in terms of consumer favour, summary of grades given to the hotel in general, the rank of hotel in region, negative reviews on hotel, personal grading of hotel, positive reviews on hotel, the pictures that users add, the titles of reviews, the number of previous reviews, the number of hotels on which users write reviews, the nationalities of reviewers.

It was concluded that hotel managers read reviews regularly, they cared and wrote replies more about negative reviews or reviews about service. What managers thought about online reviews could be summarized as follows: Online reviews affected sales, marketing efficiency increased, services were rendered in a better way, relations with guests improved, recognition of products increased, competitive advantage was provided, guest relations strengthened, purchasing decisions of consumers were affected in a positive way, they were an important tool for monitoring consumer tendencies, they helped determine guest complaints and determine how guests perceive the products.

For these reasons, hotels should give importance to online reviews and modify their services in parallel to them. In replying online reviews, what hotel managers regard as efficient is as follows: the favour rating of hotel in region, the rank of hotel in region in terms of favour, summary of grades given to hotels in general, the rank of hotel in region, negative reviews on hotel, personal grading of hotel, and positive online reviews on hotel, the pictures that online users add, the titles of online reviews, the number of previous reviews, the number of hotels on which online users write, the nationalities of reviewers. The pictures that online users add, the titles of reviews, the number of previous reviews, the number of hotels on which they write reviews, the nationalities of reviewers, the rating and the rank of the hotel within the region, the summary of scores given to hotel in general, positive and negative reviews on hotel and individual scores of the hotel have an influence upon managers' replies to the reviews. All the reviews written by consumers should be examined and responded by the relevant department.

Hotel managers should embrace online reviews, as they are important tools in determining how services are perceived. They should give primacy to positive reviews as much as negative reviews. They also should pay attention to online reviews on rooms, sleep quality, cleanliness, food and atmosphere in addition to service. Due to time constraint, the sample consisted of only 4-5 star hotels with tourism operation licenses. For further research, this study can be adapted to all accommodation facilities with tourism operation licenses. The managers of other types of accommodation facilities such as boutique hotels may be a topic for further research.

\section{REFERENCES}

Breure, E. (2013). "Hotel Reviews- Can we trust them?", http://www.olery.com/blog/infographic-hotel-reviews-can-we-trust-them/

Browning, V.; So, Kevin Kam F. and Sparks, B. (2013). "The Influence of Online Reviews on Consumers' Attributions of Service Quality and Control for Service Standards in Hotels." Journal of Travel \& Tourism Marketing, 30, pp. 23-40, DOI: 10.1080/10548408.2013.75097. 
Gu, B. and Ye, Q. (2014). "First Step in Social Media: Measuring the Influence of Online Management Responses on Customer Satisfaction." Production and Operations Management, 23 (4), pp. 570-582.

Jimenez, F. and Mendoza, Norma A. (2013). "Too Popular to Ignore: The Influence of Online Reviews on Purchase Intentions of Search and Experience Products." Journal of Interactive Marketing, 27, pp. 226-235.

Korfiatis, N. and Poulos, M. (2013). "Using online consumer reviews as a source for demographic recommendations: A case study using online travel reviews." Expert Systems with Applications, 40, pp. 5507-5515.

Lee, HyeRyeon and Blum, Shane C. (2015) "How hotel responses to online reviews differ by hotel rating: an exploratory study. Worldwide Hospitality and Tourism Themes, 7 (3), pp. 242-250.

Lee, Hee A.; Law, R. and Murghy, J. (2011). "Helpful Reviewers in TripAdvisor, an Online Travel Community." Journal of Travel \& Tourism Marketing, 28, pp. 675-688, DOI: 10.1080/10548408.2011.611739.

Levy, Stuart E.; Duan, W. and Boo, S. (2013). “An Analysis of One-Star Online Reviews and Responses in the Washington, D.C., Lodging Market." Cornell Hospitality Quarterly, 54 (1), pp. 49-63, DOI: 10.1177/1938965512464513.

Olery. (2012). https://reviewsites.olery.com/

Ong, Beng S. (2012). "The Perceived Influence of User Reviews in the Hospitality Industry." Journal of Hospitality Marketing \& Manegement, 21, pp. 463-485, DOI: 10.1080/19368623.2012.62674

Park, S. and Allen, Jonathan P. (2013). "Responding to Online Reviews: Problem Solving and Engagement in Hotels." Cornell Hospitality Quarterly, 54 (1), pp. 64-73, DOI: 10.1177/1938965512463118.

Purnawirawan, N.; Pelsmacker, Patrick D. and Dens, N. (2012). "To Respond Or Not To Respond: The Effectiveness Of Organizational Responses To Negative Online Reviews." American Marketing Association, Winter 2012, pp. 62-63.

Racherla, P., Connolly, Daniel J. and Christodoulidou, N. (2013). "What Determines Consumers' Ratings of Service Providers? An Exploratory Studyof Online Traveler Reviews." Journal of Hospitality Marketing \& Manegement, 22, pp. 135-161, DOI: 10.1080/19368623.2011.645187.

Sparks, Beverley A.; Perkins, Helen E. And Buckley, R. (2013). "Online Travel Reviews as Persuasive Communications: The Effects of Content Type, Source, and Certification Logos on Consumer Behavior." Tourism Management, 39, pp. 1-9.

Stringam, Betsy B.; Gerdes, J. and Vanleeuwen, Dawn M. (2010). "Assessing the Importance and Relationships of Ratings on UserGenerated Traveler Reviews." Journal of Quality Assurance in Hospitality \& Tourism, 11 (2), pp. 73-92, DOI: 10.1080/1528008X.2010.482000.

Treviño, T. and Castaño, R. (2013). "How should managers respond? Exploring the effects of different responses to negative online reviews." International Journal Leisure and Tourism Marketing, 3 (3), pp. 237-251.

Xie, Hui Jimmy, Miao, Li, Kuo, Pei-Jou ve Lee, Bo-Youn. (2011). “Consumers' responses to ambivalent online hotel reviews: The role of perceived source credibility and predecisional disposition." International Journal of Hospitality Management, 30, pp. 178183, DOI: 10.1016/j.ijhm.2010.04.008. 
Xie, Karen L.; Zhang, Z. and Zhang, Z. (2014). "The business value of online consumer reviews and management response to hotel performance." International Journal of Hospitality Management, 43, pp. 1-12. 